\title{
Člověk „dobrý“ a/nebo „zlý“? Antropologická varianta výchovy mezi autoritářstvím a liberalitou ${ }^{1}$
}

\author{
Jan Hábl \\ Univerzita Hradec Králové, Pedagogická fakulta, Katedra pedagogiky a psychologie
}

Redakci zasláno 27. 10. 2016 / upravená verze obdržena 16. 12. 2016 /

k uveřejnění přijato 5. 1. 2017

\begin{abstract}
Abstrakt: Cílem této studie je ukázat implikace antropologického předporozumění lidské povahy pro etické vychovatelství. První část práce prezentuje rozdíl mezi ontologickým a morálním aspektem lidské povahy, tj. rozlišuje mezi tím, jak člověk jest (ontologie) a jak by měl být (morálka). Druhá část srovnává tři, resp. čtyři antropologické varianty odpovědí na tyto otázky - antropologický pesimismus, optimismus, realismus, existencialismus. Třetí část ukazuje eticko-výchovné implikace těchto odpovědí. Na základě rozlišení ontologické a morální komplexity lidské povahy je doloženo, že antropologický realismus vede k autentické pedagogické humanizaci, zatímco pesimismus vede $\mathrm{k}$ autoritářské výchově a optimismus $\mathrm{k}$ liberální výchově. Antropologický realismus skýtá největší edukační potenciál pro funkční etické vychovatelství, které si klade za cíl formovat autentickou humanitu.
\end{abstract}

Klíčová slova: ontologie, morálka, výchova, etická výchova, dobro, zlo, lidskost

Etické či morální vychovatelství se ukazuje být stále více potřebným důrazem v edukačním úsilí současnosti. ${ }^{2}$ Fundamentální otázku, kterou si musí každý pedagog či vychovatel položit, má-li ambici jakkoli formovat charakter dítěte, jest, zda je člověk ve své podstatě dobrý nebo špatný. Dủvod je nasnadě. Je-li člověk ve své podstatě dobrý, žádnou výchovu nepotřebuje. Je-li člověk v podstatě špatný, je třeba na něj intenzivně působit. Pokusím se $\mathrm{v}$ tomto př́spěvku předložit a poskytnout argumenty pro antropologickou variantu, která předpokládá, že člověk je dobrý i zlý zároveň, resp. že je dobrý ve svém bytí (ontologicky), ale problematický ve svých činech (morálně). Nebo ještě jinak, je dobrý ve své potencialitě, ale svůj potenciál neaktualizuje vždy dobře. V první části se pokusím ukázat rozdíl mezi ontologickým

1 Tento text částečně vychází ze třetí kapitoly knihy I když se nikdo nedívá. Fundamentální otázky etického vychovatelství (Hábl, 2015). Je však významně upraven.

2 O vzestupu zájmu o etické vychovatelství pojednávám jinde. Viz např. Hábl $(2011,2015)$.

DOI: https://doi.org/10.5817/PedOr2017-1-181 
a morálním aspektem lidské povahy. Ve druhé srovnám čtyři základní antropologické varianty odpovědí na otázku, zda je člověk ve své podstatě dobrý nebo špatný s ohledem na zmíněný ontologický a morální rozměr lidství antropologický pesimismus, optimismus, realismus a existencialismus. Třetí část ukazuje eticko-výchovné implikace těchto odpovědí. Hlavním argumentem této práce je, že antropologický realismus vede k autentické pedagogické humanizaci, zatímco pesimismus vede $\mathrm{k}$ autoritářské výchově a optimismus k liberální výchově. $\mathrm{Z}$ hlediska metodologického se jedná o studii hermeneutickou, založenou na deskriptivně-syntetických, ale též deduktivních a komparativních postupech. Vybraným výchovným koncepcím kladu otázku, z jaké antropologie vycházejí, přičemž klíčovým metodickým nástrojem komparace je zmíněná ontologicko-morální distinkce. Záměrem práce není ohledávat, v čem se jednotlivá edukační pojetí překrývají, ale naopak hledat, $\mathrm{v}$ čem se liší a co z této odlišnosti plyne.

\section{Ontologický rozměr lidství}

Zdá se, že realita není triviální. Při jejím pozorování zjišt’ujeme, že je rozdíl mezi tím, co jest, a co být má. Řečeno antropologicky: člověk nějak je a nějak by měl být, resp. někdy neměl být. Fenomén „měl bych“, př́íp. „měl bys“, je v centru pozornosti všech, kdo se zabývají etickým vychovatelstvím. Odkud tento imperativ? V čem spočívá jeho legitimita? Proč se vztahuje specificky na člověka (když zvíře uloví zvíře, není to vražda)? Otázky původu, zdroje či rozsahu morality přesahují rámec této studie. Práce se omezuje pouze na pozorování antropologických skutečností. Z určitého úhlu pohledu se lidská povaha či podstata ukazuje jako komplexní, složitá, a to minimálně ve dvou rovinách - ontologické a morální. Ve svém bytí, tzn. ontologicky, je člověk nesporně dobrý nebo též důstojný, hodnotný, významný, vznešený. Je někdo. Avšak ve své morální kapacitě je ambivalentní - schopný dobrého i zlého. A nejen schopný. Dobro a zlo skutečně koná.

Tradičně se ontologická důstojnost lidské osoby odůvodňovala metafyzicky od Mojžíše přes Platóna, Aristotela, Akvinského až po našeho Komenského. Tím či oním způsobem je člověk pojímán jako bytost, která nenáleží sama sobě, ale vztahuje se k něčemu, co ji přesahuje, přičemž toto „náležení" nepředstavuje nějakou nahodilou či volitelnou psychologickou potřebu (tolik bych chtěl někoho mít a někomu patřit), ale jedná se o ontologický status, bez kterého lidství postrádá cosi podstatného (srov. Nullens \& Michener, 2010, s. 173n). Nexus hypostaticus, říkal například Komenský $(1905,1926,1946)$ 
ve svých Didaktikách, tj. bytostný vztah člověka k Posvátnému. Člověk je někdo, protože je stvořen jako Imago Dei, tj. k božímu obrazu. ${ }^{3}$ Veškeré jeho osobnostní kapacity - schopnost vědět, vědět o sobě, cítit, rozlišovat dobré a zlé, krásné a ošklivé, schopnost milovat, smát se apod. - mu byly dány, aby se z nich jednak těšil, jednak aby jimi zrcadlil a tím ctil Stvořitele jakožto summum bonum (nejvyšší myslitelné dobro, které člověk dokáže tušit). Je-li co dobré, pravdivé a krásné u člověka, není to nahodilost, ale záměr. Člověk je bytost, kterou stálo za to stvořit. Byly stvořeny i jiné bytosti, ale člověk jediný s jedinečným úkolem i výsadou - být reflexí samotného Stvořitele. Odtud jeho důstojnost. Je nezměrná a jen těžko kvantifikovatelná, říkávali naši premoderní otcové.

Toto ontologické určení člověka tradičně zakládalo jeho morální určení, onen pocit „měl bych“. Lidská bytost nějak ví nebo cítí, že by měla dostát svému povolání. Nejednat pod svou důstojnost. Měl bych tu vyplývá z toho, co jsem. Etika z ontologie. Lidskost z lidství. ${ }^{4}$

Antropologická intuice ohledně hodnoty člověka přetrvává v naší kultuře i potom, co bylo filozoficky odstraněno její odůvodnění. Modernita programově zamítla veškerou metafyziku a s ní i veškerou ontologii, přesto většina moderních (a normálních) lidí trvá na tom, že člověk nějakou skutečnou hodnotu má. Říkáme „člověk, to zní hrdě“. A hoří-li dům, zachraňujeme nejprve lidi, teprve potom věci. G. Marcel tomu říkal „ontologický cit“, což M. Petříček interpretuje jako fundamentální „potřebu bytí“ (1997, s. 87).

\section{Morální rozměr lidství}

Morální dimenze lidské povahy se ve srovnání s ontologickou ukazuje - jak už jsem naznačil - jako značně problematická. Je zřejmé, že s člověkem, resp. $\mathrm{s}$ morální kapacitou jeho povahy, není něco $\mathrm{v}$ pořádku. Člověk není schopen dostát svému určení. Ano, je tu morální imperativ, hlas, který ř́ká „měl bych“, ale já ho neposlouchám, resp. poslouchám selektivně, někdy. Aby to bylo ještě složitější, při troše poctivé introspekce zjištuji, že někdy hlas slyšet vyloženě nechci a podnikám různé kroky k jeho „přeslechnutí“. Jindy zase hlas slyším dobře, a dokonce ho chci uposlechnout, ale nedokážu to. „Neměl bych tolik kouřit.“ - „Neměl bych to brát.“ - „Tohle už nikdy neudělám." A přece se přistihnu, že to zase dělám. Zjištujuji, že vůle je (někdy) dobrá,

3 K tomuto tématu viz Nullens a Michener (2010).

4 K tématu ought-ness jakožto vnitřní (intrinsic) charakteristice lidské povahy viz A philosophy of ethics D.W. Aikena (1988). 
ale slabá. Na tomto místě je třeba dotknout se klíčové otázky - není to celé fikce? Není tento „hlas svědomí“ bič, který jsme si na sebe uměle ušili? Není to pouhý konstrukt - sociální, psychologický nebo jiný? Implikace takto položené otázky je zřejmá. Pokud ano, pak zaprvé - nemá objektivní platnost, a tudíž si na mě nemůže činit žádný nárok, zadruhé - je možné s ním libovolně zacházet, rekonstruovat ho nebo zcela dekonstruovat. Obávám se, že právě zde je jádro našeho současného problému a také důvod, proč musíme zavádět etickou výchovu do škol. Společně s Hobbesem, Darwinem, Freudem a Nietzschem jsme nejprve vysvlékli člověka z jeho důstojnosti („nejsme nic než..."), a následně i z jeho etiky („nemusíme nic než..."). A ted' si nevíme rady s morálně negramotnou generací (srov. Sokol, 2014).

Jsem přesvědčen, že s naším lidstvím i lidskostí se to má jinak. Naše důstojnost není fikcí či konstruktem. Je skutečná. A proto i morální povolání člověka je skutečné. Jakkoli může naše svědomí být obtěžkané patologickými nároky, které na něj superegoticky naložilo prostředí, je také pravda, že v mnohém jsou nároky svědomí zcela zdravé, legitimní a reálné, tzn. že to, co žádají, je skutečně dobré (nebo špatné), ne dobré „pro mě“ nebo dobré „pro mocnější většinu“ nebo „pro zájmovou skupinu“, dokonce ani ne „pro danou kulturu“, ale dobré ve své objektivní podstatě, dobré pro lidství člověka. Pravidla silničního provozu nebo pravidla stolování si lidé domluvili a bude-li třeba, mohou je kdykoli změnit. Ovšem pravidla lidskosti nepodléhají subjektivní preferenci nebo sociálnímu kontraktu, nelze o nich hlasovat ani vyjednávat. Zrádcovství, zbabělost nebo nadutost budou vždy nemorální, a to i kdyby většina (např. i celá kultura) odhlasovala, že to bude chtít jinak. ${ }^{5}$ Zákony lidské morálnosti člověk neprodukuje ani neustanovuje. Rozpoznává je. A bud' je přijímá, nebo ne.

Tato nefiktivnost či ne-subjektivita „etična“ se nám dává poznat rozmanitým způsobem. Často v běžných každodenních situacích. Uvažme např́iklad situaci obyčejné hádky nebo sporu. $V$ takových situacích slýcháváme či vyslovujeme věty jako: "Jak by se ti líbilo, kdybych něco takového provedl tobě?" - „Nepředbíhej!“ - „To se se mnou ani nerozdělíš?“ - „Že se nestydíš!“ - „To neprozrazuj.“ - „Vždyt' jsi to slíbil.“ apod. ${ }^{6}$

Viz např. kultury obsahující zcela nemorální doktríny, jako je ženská obřízka, kanibalismus nebo árijská čistota.

6 Následující dva odstavce jsou volnou parafrází zcela nadčasových Rozhlasových hovorů, které během r. 1943 pronesl C. S. Lewis pro rádio BBC za účelem povzbuzení svých spoluobčanů zkoušených II. světovou válkou. Spolu s dalšími promluvami později vyšly knižně pod názvem Mere Christianity; česky K jádru křest’anství, vydalo Nakladatelství Návrat v Praze (1993). K tématu přirozeného zákona viz též Natural law ethics (Johnson, 2005). 
Zajímavé je, že ten, kdo takové výroky vyslovuje, jimi nechce říci pouze to, že mu chování druhého člověka vadí, ale odvolává se na objektivní standard chování, jehož znalost předpokládá i u druhého. Tento předpoklad bývá přitom vzápětí potvrzen, at' už pozitivně, nebo negativně. Provinilec se zastydí a snaží se věc bud' napravit, nebo své jednání vysvětlit či omluvit. Tvrdí například, že z nějakého mimořádného důvodu potřebuje nebo je oprávněn předběhnout nebo že se přihodilo něco, co ho z povinnosti dodržet slovo vyvazuje apod. $V$ každém prŕípadě je patrné, že se oba zúčastnění dovolávají jakéhosi zákona či kritéria slušnosti, poctivosti nebo morálnosti, o kterém oba vědí. Jakkoliv bývá taková dohoda zcela „tichá", latentní, bez složité filozofické verbalizace, odvolává se na zcela reálný referenční bod - morální zákonitost, který je platný pro oba, resp. všechny zúčastněné. ${ }^{7}$ Bez tohoto bodu by jakýkoliv morální diskurz nebyl možný. Lidé by se spolu mohli utkat jako zviŕata, ale nemohli by se přít v lidském slova smyslu. Př́it se znamená, že se jeden druhému snaží ukázat, že je na omylu nebo že se nějak provinil, udělal to, co neměl. A to nikoli z hlediska mého nebo tvého hodnotového rámce, ale $\mathrm{z}$ hlediska morálky jako takové. A něco takového by nemělo smysl, pokud by mezi účastníky pře neexistovalo kritérium pro rozlišení toho, co je správné a co špatné, stejně jako by nemělo smysl říkat, že fotbalista fauloval, kdyby nebyla stanovena pravidla fotbalu. Kdyby neexistovala pravidla kopané, neexistovala by ani hra sama nebo by se mohla stát hrou velmi nebezpečnou. ${ }^{8}$

Z určitého úhlu pohledu je lidská řeč o dobrém a zlém zcela fascinující. Žijeme ve vesmíru, který zjevně obsahuje mnoho dobrého i špatného. To podivuhodné ale je, že tento vesmír také obsahuje bytosti, jako jsme my, které o tom vědí. Máme sice obtíž s exaktní definicí pojmů dobra a zla, ale umíme rozpoznat jejich skutečnost i kvalitativní rozdílnost v jejich povaze. Dobře to vyjádřil C. S. Lewis: „Člověk neřekne, že čára je křivá, nemá-li pojem, jak vypadá čára rovná“ (1993, s. 34). A jinde dodává:

Dobří můžete být pro dobro samo, pro samo zlo být špatní nemůžete. Můžete někomu prokázat laskavost, když se vůbec laskavě necítíte, jen proto, že být laskavý je správné; nikdo se však nikdy nechoval krutě jen proto, že krutost je špatná, ale jen proto, že mu byla př́ijemná nebo užitečná. Jinými slovy zlo nemůže uspět v páchání zla stejným způsobem, jakým je dobro dobré. Dobro je takř́kajíc samo sebou: špatnost je pouze pokažené dobro. A aby mohlo být pokaženo, musí dobro nejprve existovat. (Lewis, 1993, s. 38)

7 Pro krásnou ukázku intuitivního zakoušení morální reality viz Čapkovu povídku Výkřik v souboru Boží muka.

8 I fotbalově nezdatný čtenář si jistě umí představit, jak by hra vypadala, kdyby se přestalo dodržovat např. pravidlo ofsajdu nebo autu. Nebo kdyby si některý hráč přibral na pomoc basebalovou pálku. Srov. též praktické postřehy k tomuto problému T. Schirrmachera (2013). 
Nechci zatěžovat text polemikami nad definicemi pojmů, ale vzhledem $\mathrm{k}$ tomu, že Lewis činí narážky, aniž by definoval, je zde namístě dotknout se vymezení ústředních pojmů každého etického uvažování: Co je to dobro a zlo? Zřejmě nejvýstižněji a nejúsporněji to vyjádřil G. E. Moore, když vyslovil tezi, že pojem „dobra“ patř́ k těm konceptům, které „nepřipouštějí žádnou definici, [...] nebot' pomocí nich jakožto konečných pojmů se naopak musí definovat všechno ostatní, co definici připouští" (1903, kap. I. §10). ${ }^{9}$ Pojem dobra jakožto ideálu lidství tedy přijímáme jako tajemství, mysterium. Finitum non capax infinitum. ${ }^{10}$ Není v lidských silách vymezit dobro. Zlo snad - alespoň jako privatio boni ${ }^{11}$. Ale co je dobro? Jak jej vystihnout jako pojem o sobě, $v$ jeho celistvosti, všechny jeho varianty a tváře? Kant by asi řekl, že noumenon je nám nedostupný, at’ už empiricky, racionálně, nebo jakkoli jinak. A přece, když se s konkrétním dobrem setkáme, když se nám zjeví (fainomenon), poznáme a pocítíme ho. Ve výchově k jakémukoli dobru tedy vše začíná pokorou - je tu entita, která mne přesahuje, principia ethica.

Skutečnost „etična“ jakožto morálního zákona či principu dobře dokládá ještě jedno pozorování. Kromě neodbytné myšlenky, že bychom se měli chovat určitým způsobem, je tu fakt, že se tak nikdo z lidí nechová. Ne že bychom dělali bez přestání jen samé špatnosti, pouze chci poukázat na skutečnost, že - slovy C. S. Lewise - „pravděpodobně právě letos, ba tento měsíc či dokonce ještě dnes jsme se nezachovali způsobem, který očekáváme od druhých“ (1993, s. 13). Na svou obhajobu obvykle uvádíme rozmanité „polehčující okolnosti“, kterými máme tendenci se nějak „vyviňovat“, omlouvat či umlčovat onen neúprosný nárok „to bys ne/měl“. Taková sebe-obhajoba mưže mít různé podoby: „Zachoval jsem se sice nepěkně k manželce, ale byl jsem tak unavený." - „Tu spornou transakci jsem musel ututlat, jinak by hrozilo, že mě vyhodí z práce, a jak bych pak splácel hypotéku.“ - „To, co jsem slíbil sousedovi a nikdy neudělal, bych býval nesliboval, kdybych věděl, kolik se mi nahrne práce." Nejde o to, zda jsou to omluvy oprávněné, či nikoliv. Pointa těchto ilustrací je, že hlas slyšíme, máme v sobě cosi skutečného - vědomí morálního zákona. Člověku je vlastní, je se mnou, ve mně, s-vědomím. Kdyby

Citováno z online verze Principia ethica (Moore, 1903).

10 Filozofický výrok vyjadřující, že cokoli konečného (finitum) nemůže plně pojmout či pochopit nekonečné (infinitum), natož je pak definovat (definitum).

11 „Nedostatek dobra“. K problematice definice pojmů dobra a zla viz také R. Shermer (2004) nebo A. F. Holmes (2007). 
nám nebylo vlastní, neměli bychom potřebu se obhajovat, když jednáme proti němu, a naopak, neznali bychom pojem „čistého svědomí", když jednáme v souladu s ním.

Pojem „čisté svědomí“ je pochopitelně notoricky problematický, nebot’ my lidé disponujeme kromobyčejně rozmanitou škálou psychologických prostředků, které nám umožňují udržovat si svědomí subjektivně „čisté“, bez ohledu na objektivní skutečnost. Viz všechny racionalizace, projekce, suprese, kognitivní disonance a jiné strategie (srov. Aronson, 2011). ${ }^{12}$ Tím více však vyvstává potřeba etické výchovy, která by vychovávaného učila vztahovat se k morální skutečnosti náležitým způsobem, tj. kultivovat svědomí tak, aby „nebloudilo“, jak říká A. Anzenbacher, čili aby člověka obviňovalo nebo naopak obhajovalo adekvátně, v souladu s morální realitou. ${ }^{13}$

Za povšimnutí stojí ještě jeden morálně-psychologický moment s významnými vztahově-sociálními implikacemi. Obtížnost procesu připouštění viny zpravidla ústí v zajímavou etickou disproporci - za mé morální selhání může vždy něco nebo někdo jiný; morálně dobrý počin naopak vždy připisuji na vrub sám sobě. Tato disproporce se za určitých okolností může jevit jako roztomilá či komická (viz např. hlavní postava filmu Anděl na horách). Stane-li se však trvalou součástí charakteru, jedná se o tendenci veskrze tragickou, bude komplikovat život danému člověku i jeho okolí, jak dobře ví každý, kdo byl nucen potýkat se s člověkem nebo lidmi, kteří dlouhodobě trpěli neschopností připustit vlastní vinu. Zvláště tragické pak je, stane-li se tato nectnost samozřejmým atributem vlivné sociální kultury či subkultury, například politické nebo jakékoli jiné, která se dotýká společného soužití lidí. Sklon k přenosu viny bývá navíc tím intenzivnější, čím je vina skutečnější. Proto jedním z klíčových komponentů kvalitní etické výchovy je kultivace této lidsky nežádoucí tendence.

Rekapituluji: Člověk je ambivalentní bytost. Dobrá ontologicky, nedobrá morálně. Morální kapacita člověka není špatná vždy a ve všem. Disponuje vynikajícím potenciálem, a ten často užívá, jak má, ale často, ne-li častěji, jak nemá, zneužívá jej nebo nemá dostatečnou vưli jej užívat dobře. Pokud vzneseme fundamentální otázku, zda je člověk ve své podstatě dobrý, neexistuje

12 Pro př́klad velmi zdařilé strategie, jak „ulehčit“ svědomí, viz freudovskou teorii superega nebo jungovskou teorii archetypů, kde za aktuální lidské jednání nese odpovědnost vždy nějaký podmiňující faktor, takže jednající je vždy „z obliga“.

13 K problematice svědomí viz např. Anzenbacher (1994) nebo Dacík (1946). 
jednoduchá a jednoznačná odpověd'. Jednoduchá odpověd' by v tomto př́ípadě byla nutně zjednodušující, protože by ignorovala některou $\mathrm{z}$ dimenzí lidské povahy.

\section{3 Člověk: dobrý, nebo špatný?}

V jednom ze svých slavných dialogů vznáší Platón ústy Menóna klíčovou otázku, a to, zda je možné člověka naučit ctnosti? A pokud ano, jak? Snad prý skrze správné poznání? Nebo dobré návyky? Nebo je ctnost člověku přirozená? Nebo je naopak proti jeho přirozenosti a je nutné ji nějak „přeučit“? ${ }^{14}$

Rozbor Sokratovy odpovědi přesahuje možnosti této studie, ale co stojí za povšimnutí, je skutečnost, že v několika úvodních tázacích větách Platón takřka prorocky pojmenoval několik základních výchovných koncepcí, které lidstvo v následujících čtyřiadvaceti stoletích vyzkoušelo.

1) Nejoptimističtější pojetí vychází z přesvědčení, že člověk je ze své podstaty dobrý, ctnostným se stává jaksi mimochodem, přirozeně, takže žádné morální vyučování nepotřebuje. Tak to viděli a vidí všichni vychovatelé liberálního založení.

2) Druhá, stále ještě poměrně optimistická filozofie předpokládá, že ctnostným se člověk stává pravým poznáním. Kdo získá pravou moudrost, resp. pozná, co je dobré, bude také dobře jednat. K takovému poznání je však třeba náležitého vedení, učení, instrukce nebo osvícení. To je v podstatě Platónův př́stup, se specifickým důrazem na autonomii rozumu také Kantův.

3) Třetí filozofie výchovy tvrdí, že ctnost vyžaduje práci a úsilí, že je třeba cviku a návyku. Tak to viděl Aristoteles. Dle jeho soudu člověk není předem ani špatný, ani dobrý, ale dobrým se má teprve stát, a k tomu je třeba praxe, činu. Ctnostným se člověk stává ctnostným jednáním.

4) Poslední přístup předpokládá, že ctnosti se dosahuje proti lidské přirozenosti. Člověk je ze své podstaty nemorální, sobecký, až zvířecí, a má-li se stát dobrým, musí k tomu být silou, případně strachem přinucen, a tak zkrocen. Všechny autoritářsky založené přístupy stojí na tomto posledním předpokladu.

14 Viz spis Euthydémos, Menón (Platón, 2000). 
Různé antropologie, které stojí na pozadí čtyř Sokratových variant, je možné identifikovat rozlišením ontologické a morální dimenze lidské povahy. Na tomto základě má otázka, zda je člověk dobrý nebo špatný, čtyři základní odpovědi, resp. antropologické konfigurace:

1) antropologický pesimismus - jsme nedobří ontologicky i morálně;

2) antropologický romantismus - jsme dobří ontologicky i morálně;

3) antropologický realismus - jsme dobří ontologicky, ale morálně pochybní;

4) existencialismus (ateistický) - jsme ontologicky špatní, ale morálně dobří.

Jedná se o schéma, zjednodušení, které se se Sokratovým nástinem navíc překrývá jen částečně, ale i tak umožňuje určitou reflexi našeho eticko-výchovného počínání. Začněme od poslední varianty. Existenciální filozof zdůrazňuji ateistického typu ${ }^{15}$ - je přesvědčen, že ve svém bytí (ontologicky) je člověk bezvýznamný, je prostě „vržen“, zatížen bezdůvodnou existencí a s ní spojenou svobodou. Má-li život člověka nabýt jakéhokoli významu, pak jedině tím, že se rozhodne mu nějaký význam dát. $M$. Petříček interpretuje Sartra: „Zprvu tedy [člověk] není ničím: bude až potom. A bude takovým, jakým se učiní." (1997, s. 102-103). Čili existence předchází esenci. Nezáleží na tom, pro co se rozhodne, neexistuje žádná apriorní podstata člověka ani žádný transcendentní arbitr pravdy, který by posuzoval, co je dobré a co špatné. Podstatné je se rozhodnout. Sartre mluví o „úplné“ nebo „absolutní“ svobodě jako způsobu existence člověka, který je dle jeho soudu „sebe definující a sebe-determinující nicota" (převzato z Allen, 1982, s. 201). Ozvuky takto pojaté antropologie lze registrovat $v$ eticko-výchovné literatuře během druhé poloviny 20. století.

Čteme znovu a znovu, že „učení je proces, při kterém význam - etický nebo jakýkoli jiný - musí být aktivně utvářen a znovu-utvářen (invented and reinvented), a to směrem zevnitř ven" (Kohn 1997, s. 429-433). Nebo jiní autoři: „Jedinec, který je morální skutečně autonomně, žije podle pravidel, která jsou jeho vlastní, založená na principech, které si sám zkonstruoval a sám reguluje." (DeVries \& Zan, 1994, s. 46). Odtud didaktický důraz na autonomní rozhodování a volbu: „Pravé hodnoty reprezentují svobodnou a promyšlenou volbu inteligentních lidí, kteř́i jsou v interakci s komplexním a proměnlivým

15 Existencialismus se tradičně dělí na teistický a ateistický. Sartre sám ho takto dělí a hlásí se k druhému křídlu, viz jeho stručný spis Existencialismus je humanismus (2004). Teističtí existencialisté vidí lidskou situaci pochopitelně jinak (srov. Petř́iček, 1997). 
prostředím." (Raths, Harmin, \& Simon, 1978, s. 41). Ale pozor, hodnoty musejí být zvoleny svobodně, jinak by nebyly „pravé“. Nebo alespoň „zvolené z nabídnutých alternativ“, ale hlavně „po samostatné úvaze“. Imperativ svobodné volby se stal tak nedotknutelným, že pedagogové byli nabádáni, aby „dětem pomáhali hledat hodnoty, pokud [důraz můj] se proto děti rozhodnou. Je také možné, že se děti rozhodnou hodnoty nerozvíjet. Učitelovou povinností je podpořit i takové rozhodnutí." (Raths et al., 1978, s. 48). Pregnantně to vyjádřil A. Kohn (1997, s. 435): „Děti musejí být zvány k tomu, aby reflektovaly komplexní otázky, přetavily (recast) je svou vlastní zkušeností, a tím pro sebe zjistily, jakým člověkem by měly být." Jinými slovy, je to jedině volba, skrze kterou se hodnota stává vlastní. A. S. Neill, zakladatel Summerhill School, šel dokonce tak daleko, že ve jménu individuální autonomie dovolil žákům absentovat z veškeré výuky, pokud si to přáli (Neill, 1960, s. 29). A pokud Neill bojoval za svobodu ve škole, I. Illich a další „odškolovatelé“ prosazovali svobodu od školy, čili svobodu absolutní - viz texty jako Deschooling society (1970).

Pedocentrismus tohoto typu vede nutně k morálnímu subjektivismu a relativismu. ${ }^{16}$ Dobře to ilustruje př́ručka jednoho ze vzdělávacích programů s názvem Growing up caring (Vyrůstat s péči). Vybírám dva př́lklady za všechny. V kapitole pojednávající o školním podvádění žák nalezne obrázek dívky, která se při testu dívá přes rameno spolužačky. Obrázek je doprovozen textem: „Podvádění v jakékoli podobě není dobré pro tvé sebevědomí (self-esteem)." V jiné kapitole kniha ukazuje fotografii mladé ženy, která krade v obchodě, přičemž na vedlejší fotografii ji sledují dva další lidé a nahrávají průmyslovou kamerou. Doprovodný text praví: „Jeden ze způsobů, jak zjistit dopad tvého jednání na pocit tvé vlastní hodnoty (feeling of self-worth), je, když si představís fotografii zachycující tvé rozhodnutí." (cit. podle Hunter, 2000, s. 122-123). Etický argument těchto instrukcí je zřejmý - děti nejsou vedeny k tomu, aby nabyly přesvědčení, že podvádění nebo krádež je objektivně špatná věc, protože porušuje morální zákon platný univerzálně mezi lidmi. Podvod je špatný, protože vyvolá nepř́ijemné pocity, případně ohrozí sebevědomí jedince. Českého čtenáře možná napadne, že taková argumentace byla možná pouze v relativně vyspělé morální kultuře Spojených států v sedmdesátých a osmdesátých letech. $\mathrm{V}$ naší kultuře bylo tou dobou všechno jinak.

16 Ne každý pedocentrismus si zaslouží stejnou míru kritiky. Důraz na dětství jako významnou etapu života, na dětskou spontaneitu, zvídavost, hravost, citovost atd., který do diskuze vnesli myslitelé jako J. H. Pestalozzi, M. Montessori, J. Dewey a mnozí jiní, byl (a stále je) zcela na místě. Problém je, když se tento či jakýkoli jiný důraz radikalizuje nebo absolutizuje. 
Pokud se našinci podařilo něco „uloupnout“ ze státního, měl z toho vyloženě dobrý pocit. Nejen že si přilepšil, ale navíc se mohl těšit pocitem odbojového záškodnictví vůči prohnilému režimu - a to celé bylo posvěcené sloganem „kdo neokrádá stát, okrádá rodinu“. Obávám se však, že by argument „pocitem“ už dnes nefungoval - jedinců, kterým by při páchání neetických činů klesalo sebevědomí nebo by se cítili mizerně, rapidně ubývá, a to jak na Západě, tak na Východě.

Subjektivismus, který stojí v pozadí tohoto pojetí, má př́mou spojitost s „kulturami“ etického utilitarismu a emotivismu, někdy též nazývaného expresionismus (srov. Hunter, 2000). V utilitarismu morální diskurz určuje logika výhodnosti, prospěšnosti či užitečnosti, v emotivismu logika duševní pohody. V obou případech je to individuální já, které je arbitrem morální rozvahy. V tomto referenčním rámci je tím nejvýznamnějším morálním počinem akt volby. Rozhodnout se. Nikoli pro co se rozhodnout, ale rozhodnout se vůbec. A rozhodnout se za sebe. Sartre v pedagogickém hávu.

Výsledky? Subjektivisticky orientované edukační praktiky dosáhly svého, čímž se staly součástí problému, který chtěly původně řešit. Generace vychovaná v tomto duchu je vskutku autonomní, alespoň do té míry, aby vyloučila jakýkoli závazek, který by překračoval hranici subjektivní volby a osobního blaha. Je to logický důsledek programového zpochybnění objektivní morální reality. Jsem-li systematicky přesvědčován, že posledním arbitrem morálních hodnot jsem já sám, nakonec tomu uvěřím. Jsem-li metodicky ponoukán, abych sebe-určil svou podstatu skrze svobodnou volbu, nakonec to udělám. Koho by napadlo, že bych zcela svobodně mohl zvolit i zlo? Ale čekat se to dalo - minimálně už od Zimbarda a Milgrama. ${ }^{17}$ Ovšem před nimi to ř́kal už Dostojevský a také Komenský a ještě před ním Akvinský, Augustin, Pavel z Tarzu a mnozí další.

Zbývající tři varianty pojednám pospolu. V tradici antropologického realismu stojí např́íklad J. A. Komenský. ${ }^{18}$ Abychom docenili toto pojetí, uvažme konkurenční pozice. Předesílám, že koncepty, které budu črtat, jsou spí-

17 O tzv. Stanfordském vězeňském experimentu Philipa Zimbarda toho bylo mnoho napsáno (dokonce zfilmováno), rovněž tak o zkoumání lidské konformity Stenleyem Milgramem. Pro podrobnosti k Zimbardovi viz např. domovskou stránku Stranfordského experimentu $<w w w . p r i s o n e x p . o r g>$. K Milgramovi viz jeho Obedience to authority: An experimental view (2004).

18 Antropologický realizmus by bylo možné vyložit na mnoha autorech - starších i současných. Komenského volím jako exempli causa čistě z osobních a subjektivních důvodů. 
še modelovými ukázkami vyhraněných pozic. Mezi naprostou výchovnou liberalitou a naprostou totalitou stojí množství méně radikálních přístupů. Nejslavnějším proponentem, ba otcem-zakladatelem výchovného liberalismu, je J. J. Rousseau. Rozumíme zdrojům jeho teorie - reagoval na značně dekadentní, umělou a zároveň zkostnatělou společnost své éry, která na hraně novověku stále ještě setrvávala ve středověkých sociálních strukturách. Proto pryč od společnosti na venkov, do př́rody. Vidí-li Rousseau společnost jako zkaženou, jedinec je naopak v jeho očích zcela bez poskvrny. At' už v jeho Emilovi, nebo ve Vyznání slyšíme Rousseaua učit, že člověk je dobrý jak ontologicky, tak morálně. Neexistuje něco jako „dědičný hřích“, vymezuje se Rousseau vůči dobovým dogmatům. Připouští sice, že se člověk může dostat do situace, kdy „ochabne“, aniž si toho všimne, a může se prý dopustit nespravedlnosti či něčeho zlého, ale hned spěchá dodat: „I když jsme v nitru nepřestali být spravedlivými a dobrými." (1978, s. 60). ${ }^{19}$

Odtud jeho nevýchova. Rousseau romanticky věří, že dostane-li jedinec možnost ukázat se jako dobrý, stane se. To dobro tam je, nekazte ho, nechte ho samovolně - Rousseau rád říkal přirozeně - vykvést. Ontogenetické napětí mezi konceptem morálně pokažené společnosti a nepokaženým jedincem Rousseau neřeší. Jak vysvětlit, že z jedinců, kteří jsou ve své podstatě dobří, vzniká nedobrá společnost, od které je posléze potřeba utéct? Rousseau mlčí. Ale jeho romantický apel žije. Myslím, že ze dvou důvodů. Zaprvé hladí po srsti naši přirozenost. Představa, že jsme vlastně ve své podstatě v pořádku a že za to všechno může někdo jiný (ideálně někdo tak bezejmenný jako pojem „oni“ nebo „kultura“), se bude vždy setkávat s pozitivní odezvou. Další varianty viníka jsou „dědičnost“ nebo „hormony“, případně jiné determinační faktory. Zadruhé Rousseauova antropologie nesmírně usnadňuje život každému učiteli či vychovateli. Výchova založená na předpokladu, že dítě vlastně vychovávat nepotřebuje, je skutečně lákavá. Vznešená rétorika tu legitimizuje pedagogovu nečinnost. Všichni liberální vychovatelé ji budou milovat. Na obranu méně radikálních (nicméně liberálně orientovaných) vychovatelů je třeba říci, že ne všichni adoptovali bez výhrad Rousseauovu antropologickou základnu - pouze se ztotožnili s mnohými impulzy, které jeho dílo bezpochyby má - objev dětství jako svébytné etapy lidského života, důraz na spontaneitu, zvídavost, hravost apod.

19 Viz též Emil, čili o vychování (Rousseau, 1911). 
Na opačném konci antropologického spektra pozorujeme pojetí člověka, který není dobrý ani ontologicky ani morálně. Mezi prvními a nejvýznamnějšími zastánci tohoto pojetí byli např. Nicollo Machiavelli nebo Thomas Hobbes, po nich i mnozí další. Z jejich pohledu jsme v podstatě zvířata, šelmy, sice rozvinuté, ale šelmy. Ve svém slavném Leviathanovi Hobbes popisuje člověka jako pouhé materiální jsoucno, které podléhá materiálním zákonům. Poprvé zaznívá velmi nahlas, že člověk je determinovaná entita. Hledá slast, vyhýbá se strasti, zvláště pak strasti největší, kterou je smrt. V cestě mu často stojí druzí lidé, rivalové, se kterými musí bojovat o zachování života. Člověk je člověku vlkem. Sečteno - lidský život je slovy Hobbesovými „ošklivý, zvířecí a krátký" (nasty, brutish and short). ${ }^{20}$ Má-li člověk přežít, musí s druhými uzavřít (hypotetickou) dohodu: já nebudu požírat tebe, ty nebudeš požírat mě, a oba se vzdáme své svobody ve prospěch dozorce, který bude dohlížet na to, že tuto dohodu dodržujeme, př́ípadně udílet sankce za nedodržování. Dozorce neboli „suverén“ musí mít absolutní moc, aby všechny šelmy zkrotil. Totalitní režimy a autoritářské pedagogiky budou Hobbese milovat. Jestliže Rousseau a všichni romantici doporučují do přirozeného vývoje jedince nezasahovat, Hobbes a jemu podobní kážou zasahovat, jak to jen jde - tvarovat, obrábět, podmiňovat, krotit, hlídat, trestat. Jednou je člověk veskrze dobrý, podruhé veskrze špatný.

Komenský není ve své antropologii ani romantikem-optimistou, ani skeptikem-pesimistou. ${ }^{21}$ Rozpoznává ohromný potenciál člověka coby bytosti „nejdokonalejší a nejznamenitější“ ze všeho stvoření, ale také ví, že „synové lidští“ jsou plémě „zvrhlé“, „polovičaté“, „nestálé“, „zaslepené“, a vůbec, že věci lidské jsou jakoby „z kloubu vysmeknuté“ (viz jeho Didaktiky - velkou, českou a analytickou, Komenský, 1905, 1926, 1946). Antropologický realismus znamená schopnost připustit rozporuplnost lidské povahy. Komenský ví, že člověk může upadnout v „nečlověka“ (Pampaedia: II, 8, Obecná porada o nápravě věcí lidských, Komenský, 1992). Ve svém bytí je člověk bytost s nezměrnou důstojností a hodnotou - protože je mu dáno být Imago Dei. Ve svých skutcích je však pochybný - jak již bylo řečeno, ne vždy a ne ve všem, ale příliš často nedělá to, co by měl, případně dělá, co by neměl. Proto objektivně

20 Citát z Leviathana, který je dostupný v originále online (Hobbes, 2006, s. 58).

21 Pozor - nezaměňovat antropologický optimismus/pesimismus s pedagogickým optimismem/ pesimismem. Komenský byl pedagogickým optimistou právě proto, že byl antropologickým realistou, tj. věřil, že člověk není ani zcela zkažený, ani zcela v pořádku (srov. jeho antropologická pojednání, která se obvykle objevují v úvodních částech jeho pedagogických nebo emendačních děl jako např. Didaktiky, Komenský, 1905, 1926, 1946; Via lucis, Pampaedia v Obecné poradě o nápravě věcí lidských, Komenský, 1992). 
pozorujeme, že každá lidská kapacita, každý poznatek, každá dovednost, každá kompetence (třeba i školsky nabytá) může mít jak pozitivní, tak negativní aktualizaci. Mohou být použity k dobrému, ale i ke zlému. Odtud potřeba pedagogického formování charakteru - je pokažen a sám od sebe se ctnostným nestane, naopak, má sklon „zanášet se prázdnými, marnými a ničemnými věcmi“. Má-li se člověk stát tím, kým být má, musí k tomu být veden, vzděláván, humanizován. A právě zde se ukazuje jedna z největších předností Komenského antropologie. Jestliže z romantického pojetí člověka vyplývá př́lišná „liberalizace“ jedince, z pesimistického „totalizace“, pak z realismu plyne „humanizace“, zlidšt'ování, uskutečňování potenciálu, který je člověku dán, naplnění jeho bytostného povolání. Člověče, jsi někdo (ontologicky), uč se proto podle toho jednat (morálně).

Kvalita Komenského antropologie se dobře ukazuje v praktické aplikaci. Uvažme např. současnou debatu nad užíváním tělesných trestů ve výchově. Bít, či nebít? Debata se vede v duchu logiky „bud'-anebo“. Oba tábory mají jasno, jedni ř́ḱkají „ک̌rezat", ti druzí „legislativně zakázat“. V mnohých zemích Evropy už skutečně funguje, že za tělesný trest hrozí odebrání dítěte z rodiny. Komenského přístup je opět jiný, jemnější. Jeho jemná, tj. komplexní distinkce spletitosti lidské povahy mu dovoluje jít hlouběji. Jeho antropologie rozpoznávající ontologickou vznešenost člověka zabraňuje autoritářskému zacházení s jedincem jako s věcí. Dítě není „materiál“ k výchovnému obrábění. Veškeré výchovné působení je určováno důstojností lidského poslání. Odtud Komenského odmítání násilí - omnia sponte fluant, absit violentia rebus čili „necht' vše plyne přirozeně, násilí budiž vzdáleno“. ${ }^{22} \mathrm{Na}$ druhé straně, vědomí charakteristicky lidského sklonu $\mathrm{k}$ nemravnosti, kterou může vychovatel očekávat (nejen u dětí), funguje jako prevence romantické idealizace dětí jako ve své podstatě neposkvrněných, poslušných, pracovitých a po vědění toužících jedincủ. Děti (lidé) umějí být zlé, surové, kruté, častokrát jsou krutější než dospělí. Snadno se nechají ovlivnit, můžou se dostat až do patologického - Komenský říká „hříšného“ - extrému. V takovém případě Komenský připouští violentia remedia. ${ }^{23}$ Zda v člověku převládne vznešenost nad nízkostí, lidskost nad nelidskostí, závisí na mnoha faktorech, výchova patřri k jednomu z nejdůležitějších. Proto je Komenskému tak vzácná a káznění

22 Tímto mottem uvádí Komenský (1657) na titulní straně své vrcholné didaktické dílo Opera didactica omnia.

23 V Didaktice české Komenský popisuje tento stupeň následujícími slovy: „Pakli kdo zavilý jest, a povolnější taková slovná kázeň nestačuje, teprv se přijíti můž a má k skutečné trestání" (1926, s. 183). 
tak důležité - je vyjádřením respektu k bytostnému určení lidství jako takového. Nekáznit dítě (člověka), které je líné, neposlušné, zákeřné či zlomyslné, by naopak znamenalo škodit mu, pěstovat $v$ něm nelidskost, zanedbávat jeho důstojnost, ke které je povoláno.

Logika „bud'-anebo“ je zjednodušující, protože př́liš jednoduše předpokládá, že člověk je bud' dobrý, nebo zlý - je-li dobrý, nekáznit, je-li zlý, řezat. Komenský praví - parafrázuji - záleží na tom, jak dobrý či zkažený ten či onen jedinec je. Čeho se dopustil? Z jakého důvodu? Potrestám-li, čeho tím chci dosáhnout? Co je konečným cílem veškerého výchovného působení? Jaké prostředky jsou takovému cíli přiměřené? Zdá se, že Jaroslava Pešková měla velkou pravdu, když vyslovila, že Komenský nebyl „velký svými odpověd'mi na dobové otázky, ale svým tázáním, které dokázalo vyjádřit klíčové problémy dne“ (1992, s. 5).

\section{Závěr}

Nebudu v závěru zastírat svou pozici pod rouškou pseudoneutrality. Domnívám se, že antropologická varianta, která umí rozlišit ontologicko-morální jemnost lidské povahy (v našem bytí jsme dobří, v naší moralitě pochybní), se pro účinné etické vychovatelství jeví jako nejvhodnější. Není to nijak nová nebo převratná antropologie, vlastně je tak stará a tradiční, až se stává alternativní. Mám za to, že jednak zachycuje stav „věcí lidských“ velmi autenticky a realisticky, jednak zásadním způsobem definuje, co a jak se bude dít v etickém vychovávání - dobré rozvíjet, zlé přemáhat.

\section{Literatura}

Aiken, D. W. (1988). A philosophy of ethics: The birth of morals at the crossroads of myth and history. Frankfurt am Main: Peter Lang.

Anzenbacher, A. (1994). Úvod do etiky. Praha: Zvon.

Aronson, E. (2011). Social animal. New York: Worth Publishers.

Dacík, R. M. (1946). Mravouka. Olomouc: Dominikánská edice Krystal.

DeVries, R., \& Zan, B. (1994). Moral classrooms, moral children: Creating a constructivist atmosphere in early education. New York: Teachers College Press.

Hábl, J. (2011). Vzdělání mravné a nemravné: vztah poznání a ctnosti v Komenského pedagogice. Pedagogika, 61(2), 117-127.

Hábl, J. (2015). I když se nikdo nedívá. Fundamentální otázky etického vychovatelství. Červený Kostelec: Nakladatelství Pavel Mervart. 
Hobbes, T. (2006). Leviathan. Dostupné z http://www.earlymoderntexts.com/assets/pdfs/ hobbes1651part1_2.pdf\#page=1\&zoom=auto,-229,445

Holmes, A. F. (2007). Ethics: Approaching moral decisions. Downers Grove: Inter Varsity Press.

Hunter, J. D. (2000). The death of character: Moral education in an age without good or evil. New York: Basic Books.

Illich, I. (1970). Deschooling society. New York: Harper and Row.

Johnson, T. K. (2005). Natural law ethics. Bonn: Verlag für Kultur und Wissenschaft.

Kohn, A. (1997). How not to teach values: A critical look at character education. Phi Delta Kappan, 78(6), 428-439.

Komenský, J. A. (1657). Opera didactica omnia. Amsterodam.

Komenský, J. A. (1905). Didaktika velká. Praha: Dědictví Komenského.

Komenský, J. A. (1926). Didaktika česká. Praha: Národní knihtiskárna I. L. Kober v Praze.

Komenský, J. A. (1946). Didaktika analytická. Praha: Samcovo knihkupectví.

Komenský, J. A. (1992). Obecná porada o nápravě věcí lidských, sv. I, II, III. Praha: Svoboda.

Lewis, C. S. (1993). Mere christianity. New York: Macmillan Publishers.

Milgram, S. (2004). Obedience to authority: An experimental view. New York: HarperCollins.

Moore, G. E. (1903). Principia ethica. Dostupné z http://fair-use.org/g-e-moore/principia-ethica

Neill, A. S. (1960). Summerhill: A radical approach to child rearing. New York: Hart.

Nullens, P., \& Michener, R. T. (2010). The matrix of christian ethics. Integrating philosophy and moral theology in a postmodern context. Downers Grove: Inter Varsity Press.

Pešková, J. (1992). Aktuální aspekty filosofické argumentace v Komenského „Konsultaci“. Filosofický časopis, 40(1), 5.

Petříček, M. (1997). Úvod do současné filosofie. Praha: Herman \& synové.

Platón. (2000). Euthydémos, Menón. Praha: Oikoymenh.

Raths, L. E., Harmin, M., \& Simon, S. B. (1978). Values and teaching: Working with values in the classroom. Columbus: Charles E. Merrill.

Rousseau, J. J. (1911). Emil, čili o vychování. Praha: Dědictví Komenského.

Rousseau, J. J. (1978). Vyznání. Praha: Odeon.

Sartre, J. P. (2004). Existencialismus je humanismus. Praha: Vyšehrad.

Shermer, M. (2004). The science of good \& evil. New York: Time Books.

Schirrmacher, T. (2013). Leadership and ethical responsibility: The three aspects of every decision. Bonn: Verlag für Kultur und Wissenschaft.

Sokol, J. (2014). Etika, život, instituce. Pokus o praktickou filosofii. Praha: Vyšehrad. Stanford Prison Experiment. (1999). Dostupné z http://www.prisonexp.org/

\section{Autor}

Doc. PhDr. Jan Hábl, Ph.D., Univerzita Hradec Králové, Pedagogická fakulta, Katedra pedagogiky a psychologie, Hradecká 1227/4, 50003 Hradec Králové, e-mail: jan.habl@uhk.cz 


\title{
Human being: Good and/or evil? Anthropological position between authoritarian and liberal approach to education
}

\begin{abstract}
The purpose is to show the implications of anthropological preunderstanding of human nature to moral education. The first part distinguishes the difference between ontological and moral aspect of human nature. That is, it differentiates between who a human being is (ontology) and who he or she is to be (morality). The second part compares three, resp. four anthropological variants dealing with these aspects - anthropological pessimism, optimism, realism and existentialism. The third part shows the educational implications of these variants. The anthropological pre-understanding which distinguishes the ontological and moral complexity of human nature leads to authentic educational humanization, in contrast to anthropological pessimism that leads to authoritarian education and optimism that leads to liberalistic education. Anthropological realism offers the best potential for effective moral education that strives for formation of authentic humanity.
\end{abstract}

Keywords: ontology, morality, education, moral education, good, evil, humanity

Strouhal, M. (Ed.). (2017). Učit se být učitelem. Praha: Karolinum.

Cílem knihy je přispět k diskusi o žádoucí podobě učitelského vzdělání. Kniha představuje texty autorů, kteří se dlouhodobě zabývají otázkami učitelské profese a učitelského vzdělávání v kontextu filosofie a sociologie výchovy, vysokoškolské didaktiky, osobnostně sociálního rozvoje i samotné pedeutologie. $\mathrm{V}$ pluralitě uvedených perspektiv autoři diskutují o následujících tematických okruzích: důsledky absence ideje vzdělanosti pro univerzitní provoz a učitelskou přípravu; význam filosofického vzdělání budoucích učitelů; vztah akademického a kompetenčního diskursu a problematické důsledky procesu masifikace vzdělávání a neoliberální rétoriky; různé podoby vztahu mezi teorií a praxí v kontextu vyučování pedagogiky a psychologie na fakultách připravujících budoucí učitele; perspektivy vysokoškolské didaktiky; problematika profesních kompetencí vzdělavatelů budoucích učitelů s využitím konceptu „učitele v roli modelu“. 